\title{
Knowledge, Attitude and Behaviour of Farmer on Integrated Crop Management for Healthy Citrus Orchard (ICMHCO) in Gianyar District
}

\section{Suharyanto, Nyoman Ngurah Arya, and Putu Sutami}

Assessment Institute for Agricutural Technology (AIAT) Bali Jl. Bypass Ngurah Rai, Pesanggaran, Denpasar 80222, Bali, Indonesia

\section{Abstract}

One cause of low productivity and quality of citrus in Indonesia is not free of CVPD (Citrus Vein Phloem Degeneration) or Huang Lung Bin (HLB) disease in several citrus production centers. Integrated Crop Management for Healthy Citrus Orchard (ICMHCO) is a HLB control strategy consisted of (a) the used of labeled and free diseases

Corresponding Author: Suharyanto suharyanto.bali@gmail.com

Received: 28 July 2017

Accepted: 14 September 2017

Published: 23 November 2017

Publishing services provided by Knowledge E

(c) Suharyanto et al. This article is distributed under the terms of the Creative

Commons Attribution License, which permits unrestricted use and redistribution provided that the original author and source are credited.

Selection and Peer-review under the responsibility of the ICSAFS Conference Committee.

\section{G OPEN ACCESS} planting materials, (b) pest and diseases control especially for the HLB vector, (c) good field sanitation, (d) optimum cultural practices, and (e) field management consolidation. The research objective was to determine the knowledge, attitudes and behavior of farmers in the control HLB. The research was conducted in the village of Pupuan, Tegallalang Sub-district, Gianyar District on August 2015, using a survey of 30 farmers of respondents. Data were analyzed descriptively uses the cross tabulation. The results showed that the knowledge of farmers on ICMHCO could be classified as moderate, relatively neutral attitude of farmers and farmers' behavior is low. Efforts should be made to improve the implementation of ICMHCO, among others, by increasing the availability of seed labeled and free of disease and other production inputs, training and institutional capacity building of farmer groups.

Keywords: knowledge; attitude; behavior; citrus farmer.

\section{Introduction}

Citrus is one of the leading horticultural commodity in Bali Province that can grow and produce in the lowlands to highlands area, both in rice fields or upland. Total area of citrus plantation in the province of Bali in 2014 reached 3212.082 ha with a production of 98523.9 tons and average productivity of 30.67 tons per hectare. Gianyar District is the second highest citrus production centers in the province of Bali after Bangli. Efforts to increase the production and quality of citrus plants is hampered by low levels of technology adoption by farmers, yet unrestrained production areas of Citrus Vein 
Phloem Degeneration (CVPD) or Huang Lung Bin (HLB) disease and farm management are not optimal by the farmers.

HLB disease caused by Candidatus liberobacter asiaticum [1] including gram-negative bacteria [2] and can be transmitted by insect vectors Diaphorina citri [3]. Basically the control of the disease has been formulated and should be applied as a whole is by using citrus seed certified free of disease, control of insect vectors, perform field sanitation, and consequently, the maintenance of optimal, as well as the application of technology are integrated in a group in an area of development known as Integrated Crop Management for Healthy Citrus Orchard (ICMHCO) approach [4]. One of the obstacles in the implementation of the control strategy is field sanitation, limited the ability of farmers or workers in the field determines the HLB symptoms causing delayed eradication and orchard sanitation. Until now, visual detection is still difficult to accurately remember the attack symptoms similar to nutrient deficiency of zinc $(\mathrm{Zn})$, or mixed with other physiological symptoms. In addition, HLB infections also cause symptoms of nutrient deficiencies due to metabolic disturbances and translocation of photosynthesis and nutrients in plant tissue. Research results [5] identified that the spread of HLB region using PCR detection techniques, the spread of HLB in North Bali especially found in areas with an altitude of $10-700 \mathrm{~m}$. In the citrus growing area with an altitude of 850$1250 \mathrm{~m}$ HLB disease was not found.

Despite being stricken with a serious diseases, it turns out that citrus farming is still profitable for farmers [6]. Hence, the suggestion to undertake eradication of infected plants totally is unlikely to succeed unless farmers are given compensation for loss of income due to the destruction of the plant. It was also stated that the use of diseasefree citrus seedlings is strictly required primarily for the expansion of cultivation in the new area. It required several steps, namely (a) prohibits the citrus breeder that have been infected with the support of government regulation, (b) promote the nursery technology for citrus disease-free to groups of breeders, so the technology is widely spread, (c) provide initial subsidies for the use of disease-free citrus seedlings so the price will be lower or equal to the local citrus seedlings.

The final decision of farmers to use a new practice like ICMHCO is usually the result of their knowledge of the practices as well as their perception. The purpose of this preliminary study was to investigate the level of knowledge, attitude, and also practices of citrus farmers towards ICMHCO.

\section{Materials and Method}

The study was conducted at one site in Gianyar Citrus Agribusiness Development Region, Pupuan Vilage, Tegallalang Subdistrict which is a citrus production center in Gianyar District. Data collection was conducted in August 2015 by survey method. Data 
collected consist of primary and secondary data. Primary data collection from farmers who ever received ICMHCO farmers field school in citrus farming is done through interviews using a questionnaire, while secondary data was collected from the local Agriculture Department and related agencies. Respondents were selected purposively, as many as 30 farmers from Giri Mukti Farmers' Groups. Primary data collected were knowledge, attitudes and behavior of farmers to technology introduced by ICMHCO.

Data were analyzed using simple statistics, scoring and qualitative interpretation of the answers raised by the respondents farmer. To determine the level of farmer behaviour in HLB disease control, the score include: (a) the use of labeled citrus seed and free of disease, (b) pest control, (c) field sanitation is good, (d) the optimum maintenance, and (e) the consolidated management of the orchard with farmer groups as the smallest unit of coaching (Table 1). Each category of knowledge, attitudes and behaviour of farmers are categorized into three classes. The value of the score given to behaviour of farmers were: (1) almost never, (2) sometimes, and (3) often, to aspects of knowledge: (1) low, (2) moderate, (3) high while that for aspects of attitude: (1) disagree, (2) doubtful and (3) agree. Scores obtained from each questions were summed to obtain a total score of level of knowledge, attitudes and behaviour of farmers towards ICMHCO then categorized into three classes, using the interval formula [7]:

$$
I=\frac{D}{C}
$$

where as:

$\mathrm{I}=$ Class interval

$\mathrm{D}=$ Distance between the maximum and minimum scores

$C=$ Number of classes used

\section{Results and Discussions}

\subsection{Bio-ecological HLB disease and symptoms damage}

Citrus psyllid $D$. citri Kuwayama is an important pest in citrus crops because of their role as vectors of disease HLB. Citrus psyllid during its development has three life stages, namely egg, nymph and adult. Life cycle from egg to adult lasts for 16-18 days in hot conditions, while in the cold conditions this lice can survive up to 45 days. D. citri eggs laid in primordial buds are not yet fully developed and nymphs that hatch will move to the lower leaf surface. An adult female lays about 500-800 eggs during her lifetime. Adult insects constantly reproduce, so in one year they able to produce 9-10 generation of lice. Citrus psyllid is interested to young shoots as place for laying of eggs, thus making patterns of germination of plants is an important factor in breeding [8]. 
TABLE 1: Description of ICMHCO and Assessment Scale.

No

1.

2.

Pests and diseases control (Yellow trap application, California paste application, Drenching of insecticide solution, Insecticides spray, Sex pheromone application, and Fruit wrapping Fungicide spray)

3.

Field sanitation(Pruned diseased plant parts, Eradication of HLB infected plants, Replanting with labeled planting materials)

4. Plantation caring(Pruning of plant architecture, Maintenance pruning, Land preparation, Balance fertilizers application, Irrigation, Fruit thinning, weeds control and Good harvesting practices)

5. Consolidation of orchard management

Total scale

\begin{tabular}{|c|c|c|}
\hline \multicolumn{3}{|c|}{ The choice of respondents } \\
\hline Low/Negative & Medium/Neutral & High/Positive \\
\hline $\begin{array}{l}\text { knowing; } \\
\text { disagree; almost } \\
\text { never }\end{array}$ & $\begin{array}{l}\text { Do not know; } \\
\text { doubtful; } \\
\text { sometimes }\end{array}$ & $\begin{array}{l}\text { knowing; agree; } \\
\text { often }\end{array}$ \\
\hline $\begin{array}{l}\text { knowing; } \\
\text { disagree; almost } \\
\text { never }\end{array}$ & $\begin{array}{l}\text { Do not know; } \\
\text { doubtful; } \\
\text { sometimes }\end{array}$ & $\begin{array}{l}\text { knowing; agree; } \\
\text { often }\end{array}$ \\
\hline $\begin{array}{l}\text { knowing; } \\
\text { disagree; almost } \\
\text { never }\end{array}$ & $\begin{array}{l}\text { Do not know; } \\
\text { doubtful; } \\
\text { sometimes }\end{array}$ & $\begin{array}{l}\text { knowing; agree; } \\
\text { often }\end{array}$ \\
\hline $\begin{array}{l}\text { knowing; } \\
\text { disagree; almost } \\
\text { never }\end{array}$ & $\begin{array}{l}\text { Do not know; } \\
\text { doubtful; } \\
\text { sometimes }\end{array}$ & $\begin{array}{l}\text { knowing; agree; } \\
\text { often }\end{array}$ \\
\hline $\begin{array}{l}\text { knowing; } \\
\text { disagree; almost } \\
\text { never }\end{array}$ & $\begin{array}{l}\text { Do not know; } \\
\text { doubtful; } \\
\text { sometimes }\end{array}$ & $\begin{array}{l}\text { knowing; agree; } \\
\text { often }\end{array}$ \\
\hline $10.00-16.67$ & $16-68-23.34$ & $23.35-30.00$ \\
\hline
\end{tabular}

The early symptoms of HLB disease can be identified by the 'blotching/molting', namely mottled yellow leaves with irregular pattern and is usually not symmetrical between the left and right leaf. At first glance, the symptoms are very similar to leaf deficient micro-nutrients $\mathrm{Zn}$. The translucent yellow color to the back of the leaf so as to observe the affected leaves HLB, the lower leaf surface must be clean of insects and fungi. In the subsequent symptoms, it can lead to stunted leaf growth exhibited by the leaves shrink, relatively stiff, spiky and facing upward. HLB-infected trees budding patterns tend to be more frequent [2].

Another study stated that healthy citrus trees infected with HLB through sector vectors usually cause symptoms, i.e only in certain parts of the canopy; whereas if it had been attacked by HLB since the seedlings, the plants will grow slow and miserable [9]. HLB spread of pathogens in the phloem tissue of leaves is relatively slow compared to that caused by pathogens of other systemic symptoms such as Tristeza; symptoms spread to all parts of the canopy is caused by the vector compared to that of the movement of pathogens in plant tissue. The fruit of the tree that has been attacked by HLB, if splitted from top to bottom, visible part of the fruit are not symmetrical ("lop-sided") and seeds abortion, no pithy and tip brown beans. 


\subsection{Characteristics of Respondents and Citrus Orchard}

In general, the average age of farmers respondents was 32.46 with a range of 2152 years, this indicates that the age of farmers in the study site was very diverse, which means there are young people who are interested in agriculture, especially citrus farming. The level of formal education is an important factor to determine the level of human resources. The average level of education of farmers was finished junior high school, although there were some farmers who do not finish primary school at all. The highest education level was a high school graduate. The higher the level of formal education of farmers, the more rational pattern of thinking, and the power of reason. Education is a learning media to improve knowledge, which will further instill the attitude and affect the ability of farmers to be able to act in a more rational way and easier to accept innovation. While the experience of farmers cultivate citrus plants were also very varied in the range of 2- 12 years with an average of over 4.8 years of experience. Experience possessed by these farmers can actually be used as an opportunity towards improving efficiency in the use of production input because most farmers manage their business based on their experience.

Most of citrus production in Gianyar comes from Tegallalang Sub district which comprise of $89.76 \%$ from total production [10]. Citrus farmers generally apply intercropping or diversification with some vegetable crops in one plot with different cropping patterns. In addition to citrus farming, they have other livelihoods, namely craftsman $(24 \%)$, vegetable farming $(17 \%)$, raising cattle $(12 \%)$, trade $(4 \%)$, and as the village board $(2 \%)$ and others ( $8 \%)$.

Land size of citrus farming ranging from 0.20 -0.80 ha with an average tree population of 184 or measuring 0.32 ha with varying spacing of $3 \times 2 \mathrm{~m}, 3 \times 3 \mathrm{~m}$ and even $3 \times 4 \mathrm{~m}$. The dominant citrus varieties grown are Kintamani citrus although there are some varieties such as Siam Madu with the age range of 1-6 years with average of 3.8 years. According to Reference [11], the scale of farming citrus trees of 100-200, 201-300 trees, tree 301-400, and >400 trees worth developing because it meets the investment property value, namely $B C$ ratio $>1$, with best farming scale is $301-400$ tree because it has value $B C$ ratio of 2.06 and IRR 55.67.

\subsection{Farmers Knowledge against ICMHCO}

Knowledge is the perception at the initial stage which then form attitudes and ultimately create the act or acts. A good insight about something may leads to a better attitude, which in turn promotes behavioral change. As presented in Table 2, the level of knowledge of farmers in terms of implementation ICMHCO was classified in the medium (53.33\%), low (20\%) and high (26.67\%) category. The low level of knowledge 
TABLE 2: Farmer knowledge level of the ICMHCO in Pupuan Village, District Tegallalang, Gianyar, 2015.

\begin{tabular}{|c|c|c|c|c|} 
No & Classification / Score & The average score & Number of Farmers (people) & $(\%)$ \\
\hline 1 & Low (10.00-16.67) & 14.50 & 6 & 20.00 \\
\hline 2 & Medium (16.68-23.34) & 19.55 & 16 & 53.33 \\
\hline 3 & High (23.35-30.00) & 25.54 & 8 & 26.67 \\
\hline & Total & 18.75 & 30 & 100
\end{tabular}

of farmers in terms of controlling HLB will certainly have an impact on the level of attack and behavior of farmers in controlling the disease. This is related to the education level of farmer respondents which averaged at primary school education (39\%). Farmers' knowledge is very helpful and bolster their ability to adopt technology in farming and sustainable farming $[12,13]$. The higher the level of knowledge of farmers, the better the ability to adopt technology and vice versa. Thus the first step that must be done in terms of disease control HLB is socialization to provide insight to farmers on bio-ecology and the symptoms of the damage caused by the disease and the impact HLB citrus crop losses if heavily infected.

Thus knowledge of the early stages of the perception which then creates attitudes and in turn creates a deed or action. Good knowledge about something will encourage behaviour changes as indicated by other study [14] that the knowledge of the benefits of something will cause a person to be positive about it. Intents to participate in an activity, highly dependent on whether a person has a positive attitude towards these activities. The existence of a genuine intention to carry out an activity may ultimately determine whether the activity actually carried out. Thus farmers who have a positive outlook to ICMHCO can encourage to apply ICMHCO on their farming. One of the obstacles to free citrus orchards of HLB disease was less widely available diseasefree citrus seedlings and farmers lack of knowledge about ICMHCO [15].

\subsection{Farmers Attitude against ICMHCO}

Farmer's attitude towards technological innovation is highly dependent on the knowledge and experience of their field. As presented in Table 3, most of farmer response to ICMHCO was neutral (66.67\%). Those of farmers giving positive response were $23.33 \%$ and the ones with negative response were $10 \%$. This indicates that farmers are still hesitant to adopt ICMHCO technologies that they have just know. To solve this problem, further agricultural extension program coupled with field practice should be done to further reassure farmers that increased production of citrus with ICMHCO approach can actually reduce the level of pest attacks, although not to eliminate altogether, because as we know HLB disease is very easy to spread from one location to another. 
TABLE 3: Farmer Responses to ICMHCO implementation in Pupuan Village, District Tegallalang, Gianyar, 2015 .

\begin{tabular}{l|c|c|c|c|}
\hline No & Classification / Score & The average score & Number of Farmers (people) & $(\%)$ \\
\hline 1 & Negative (10.00-16.67) & 16.33 & 3 & 10.00 \\
\hline 2 & Neutral (16.68-23.34) & 22.64 & 20 & 66.67 \\
\hline 3 & Positive (23.35-30.00) & 25.33 & 7 & 23.33 \\
\hline & Total & 22.63 & 30 & 100
\end{tabular}

Attitude is a potential driver of the individual to react to the environment. Attitude is not forever fixed but can be changed due to the influence of others through social interaction. In social interaction, interplay occurs between individuals to one another. Individuals react to form a pattern of a certain attitude towards various psychological object faces. Among the various factors that influence the formation of attitudes are personal experience and culture. Others things considered important are mass media, affiliated institutions, educational institutions and religious institutions, as well as emotional factors within the individual [16]. Attitudes gained through experience will cause a direct influence on subsequent behavior.

\subsection{Farmers Behaviour Against ICMHCO}

The level of farmers' behaviour to ICMHCO in Pupuan Village, Tegallalang, Gianyar District, on average, are included in the category of low (70\%) with a score of 15.09 (Table 4). This is allegedly closely associated with the level of knowledge of farmers in terms of controlling HLB dominated in the medium category (53.33\%). The collected data showed that not all components and subcomponents of ICMHCO technology ever applied by citrus farmers in Gianyar. Some components and subcomponents of ICMHCO technology, such as the use of seed labelled and free of disease, yellow trap application, California paste application, drenching of insecticide solution, insecticides spray, sex pheromone application, and fruit wrapping, fungicide spray, pruned diseased plant parts, eradication of HLB infected plants, replanting with labelled planting materials, pruning of plant architecture, maintenance pruning, land preparation, balanced fertilizers application, irrigation, fruit thinning,weeds control, good harvesting practices and the consolidated management of the orchard were almost never implemented by the farmers because most of them were new to them. Some of farmer usually mixed the chemical material for once application to combat diseases. This might be due to the knowledge constrain of the farmers whereby the farmers do not know or never been informed about the alternative methods or environmentally friendly methods that can be used to control pests [16-18].

Reference [19] stated that the application of innovation behavior is influenced by several factors, internal and external ones. Internal factors include age, education, 
TABLE 4: Behavior of farmers against ICMHCO in Pupuan Village, District Tegallalang, Gianyar, 2015.

\begin{tabular}{|c|c|c|c|c|} 
No & Classification / Score & The average score & Number of Farmers (people) & $(\%)$ \\
\hline 1 & Low (10.00-16.67) & 15.09 & 21 & 70.00 \\
\hline 2 & Medium (16.68-23.34) & 18.50 & 4 & 13.33 \\
\hline 3 & High (23.35-30.00) & 24.60 & 5 & 16.67 \\
\hline & Total & 15.95 & 30 & 100
\end{tabular}

social status, relationship patterns attitudes toward renewal, the courage to take risks, fatalism, aspirations and dogmatic (closed belief system). External factors include, among others: cosmopolitan trait, distance to the source of information, the frequency of attending the extension programs, infrastructure and facilities, and the process of obtaining the means of production. A study about the characteristic of innovation and applications of ICMHCO in citrus agribusiness development in Sambas District, West Kalimantan showed that the main factors affecting the level of technology adoption is a gain factor, compliance, and complexity of the technology compared to that of the existing one [17]. On the other hand, Reference [11] show that there are differences in knowledge and behavior are based on a scale peasant farming.

\section{Conclusion}

The level of farmer's knowledge on ICMHCO as a strategy to control HLB were generally included in the medium category (53.33\%). The attitude of the average farmers $(6.67 \%)$ were neutral toward ICMHCO with an average score of 22.63 . While farmers' behavior towards ICMHCO were mostly in the low category (70\%) and only $16.67 \%$ were included in the high category. The low level of farmers' behavior towards ICMHCO was due to lack of information of the farmers on ICMHCO as HLB control strategy. This was supported by the level of knowledge of farmers which belong to the medium category.

To further improve the knowledge, attitudes and behaviour of farmers to ICMHCO the efforts that need to be taken, among others by extension program with field practice (farmers field school) through a pilot project on a larger scale. By this, it can be expected that the adoption process will run faster.

\section{References}

[1] Jaqoueix S., J.M Bove, and M. Garnier 1996. PCR detection of the two candidatus Liberobacter species associated with greening disease of citrus. Molecular and Cellular Probes. 10:43-50. 
[2] Garnier, M. and J. M. Bove. 1993. Transmission of the organism associated with citrus greening disease from sweet orange to peri winkle by dodder. Phytopathol.73:13581363.

[3] Tirtawidjaja, S. 1983. CVPD penyakit yang sangat merusak jeruk. J. Penel. dan Pengemb.Pert. 2 (1): 36-41.

[4] Supriyanto, A., M.E. Dwiastuti, A. Triwiratno, O. Endarto dan Suhariyono. 2010. Pengelolaan Terpadu Kebun Jeruk Sehat. Strategi pengendalian CVPD. Balai Penelitian Tanaman Jeruk dan Buah Subtropika. Pusat Penelitian dan Pengembangan Hortikultura. Badan Penelitian dan Pengembangan Pertanian. Kementerian Pertanian.

[5] Dwiastuti, M.E., A. Triwiratno, A. Supriyanto, M. Garnier, dan J.M. Bove. 2003. Deteksi Penyebaran Geografis Penyakit CVPD di Bali Utara dengan Metode Polymerase Chain Reaction. J. Hort. 13 (2):138-145.

[6] Saptana dan T. Sudaryanto. 1995. Analisis Sistem Agribisnis Jeruk di Jawa Timur. J.Hort. 5 (2): 14-22.

[7] Dajan, A. 1996. Pengantar Metode Statistik. Jilid II. Penerbit LP3ES. Jakarta

[8] Hall, D G., M L. Richardson, El-D Ammar and S.E.Halbert. 2012. Asian citrus psyllid, Diaphorina citri, vector of citrus huanglongbing disease. Entomologia Experimentalis et Applicata 146: 207-223.

[9] BPS Provinsi Bali. 2014. Statistik Hortikultura Provinsi Bali 2014. Badan Pusat Statistik Provinsi Bali. 2014. Denpasar.

[10] Taufik, M. 1999. Skala Usaha Tani dan Sistem Pemasaran Jeruk Siem di Sulawesi Selatan. J.Hort. 9 (2):172-187.

[11] Hothongcum, H., O. Suwunnamek and S. Suwanmaneepong. 2014. Assessment of Farmers Knowledge and Attitude Towards The Commercialitation of Tailor-made Fertilizers in Thailand. Asian Journal of Scientific Research 7 (3): 354-365

[12] Sudarta, W. 2002. Pengetahuan dan Sikap Petani Terhadap Pengendalian Hama Terpadu. Jurnal Sosial Ekonomi Pertanian dan Agribisnis. SOCA I (2): 31 - 34.

[13] Ancok, D. 1997. Teknik Penyusunan Skala Pengukuran. Pusat Penelitian Kependudukan Universitas Gadjah Mada. Yogyakarta.

[14] Indrasti, R., A. Muharam and J. Pitono. 2013. The assessment on the implementation of Integrated Crop Management of Healthy Citrus Orchards (IMHCO) to increase good quality citrus production in Garut District West Java Province. Crop \& Environment 4 (1): 51-54.

[15] Azwar, S. 2000. Sikap Manusia Teori dan Pengukurannya. Edisi ke 2. Cetakan IV. Pustaka Pelajar. Yogyakarta.

[16] Assis, K. and M. Ismail. 2011. Knowledge, Attitude and Practices of Farmers Towards Organic Farming. International Journal of Economics and Research. 2 (3): 01-06 
[17] Ridwan, H.K., A. Ruswandi, Winarno, A. Muharam, dan Hardiyanto. 2008. Sifat Inovasi dan Aplikasi Teknologi Pengelolaan Terpadu Kebun Jeruk Sehat dalam Pengembangan Agribisnis Jeruk di Kabupaten Sambas, Kalimantan Barat. J. Hort 18 (4): 477-490.

[18] Ridwan, H.K, Sabari, S.B. Rofik, S. Rahman, dan R. Agus. 2010. Adopsi Inovasi Teknologi Pengelolaan Terpadu Kebun Jeruk Sehat (PTKJS) di Kabupaten Ponorogo, Jawa Timur. J. Hort. 20 (1): 96-102

[19] Soekartawi. 2005. Prinsip Dasar Komunikasi Pertanian. Penerbit UI Press. Jakarta. 137 hal. 